$\xi=$

\title{
Production of ethanol and clarification of apple juice by pectinase enzyme produced from Aspergillus terreus NCFT 4269.10
}

\author{
Bijay Kumar Sethi ${ }^{1}$, Amrita Satapathy ${ }^{1}$, Subodh Kumar Tripathy ${ }^{1}$, Siddhartha Parida ${ }^{1}$, \\ Sameer Kumar Singdevsachan ${ }^{1}$, Bikash Chandra Behera ${ }^{2}$ \\ ${ }^{I}$ Department of Biotechnology, MITS School of Biotechnology, 2(P), Infocity, Patia, \\ Chandaka Industrial Estate, Bhubaneswar-751024, Odisha, India \\ ${ }^{2}$ Department of Biotechnology, North Orissa University, Baripada-757003, Odisha, India \\ *Corresponding author E-mail:reach4bijay@gmail.com
}

\begin{abstract}
Aspergillus terreus NCFT 4269.10 was evaluated by liquid static surface fermentation (LSSF), shaking fermentation (ShF) and solid state fermentation (SSF) for the production of pectinase. Among various substrates tested, banana peels supported maximum production of pectinase i.e. $1000 \pm 141.42 \mathrm{U} / \mathrm{ml}$. The biomass of $A$. terreus was maximum with wheat bran $(0.55 \pm 0.07 \mathrm{~g} / 50 \mathrm{ml})$. Pectinase produced by $A$. terreus displayed higher specific activity when wheat bran was used as the sole source of carbon and energy. After successful fermentation, crude enzyme was purified to electrophoretic homogeneity with a specific activity of $1846.50 \mathrm{U} / \mathrm{mg}$ from an initial specific activity of $1282.05 \mathrm{U} / \mathrm{mg}$. The cell free-dialyzed-enzyme containing $107100 \mathrm{U}$ was purified to 1.44 fold with an overall enzyme yield of $35.70 \%$.Immobilization study revealed that the production of pectinase was increased up to third cycle and decreased thereafter when further pectinase production was carried out by immobilized spores of A. terreus.
\end{abstract}

Keywords:Aspergillus terreus; Banana Peels; Fermentation; Wheat Bran.

\section{Introduction}

Pectinases are the complex hydrolytic enzymes that include pectin esterase (EC. 3.1. 1.11) which catalyzes the hydrolysis of methylated carboxylic ester groups in pectin into pectic acid and methanol. Pectinases are one of the highflying enzymes of contemporary biotechnology industries, especially, in juice preparation and food industries (Kashyap et al. 2001), paper and pulp industries (Beg et al. 2001; Viikari et al. 2001). It has been reported that microbial pectinases account for $25 \%$ of the global food enzyme sales (Sethi et al. 2016). Among all the microbial pectinases, fungal sources are the most preferred one (Singh et al. 1999).

Pectinolytic enzymes can be derived from different sources (Namasivayam et al. 2011). However, pectinase producing microorganisms have due advantage over other sources because they can be subjected to genetic and environmental manipulations to increase yield (Vibha and Neelam 2010). Submerged fermentation $(\mathrm{SmF})$ and solid state fermentation (SSF) have been successfully used in pectinase production by fungi (Pedrolli et al. 2008). Submerged fermentation is a well-developed system used in industrial scale to produce a large variety of microbial metabolites. SmF is technically easier than SSF and has been strongly developed from 1940s onwards. Microbial pectinase can be stated as the most important enzyme for the juice industry. Although, pectinase production is an inherent property of most of the organisms, only those microbes that produce a substantial amount of extracellular pectinase are of industrial importance and have been exploited commercially. Among these, strains of Aspergillus species dominate the industrial sector.

Pectinases are widely used in the food industries in the production of juices, fruit drinks and wines (Semenova et al. 2006). Pecti- nases are widely used in extraction, clarification and removal of pectin in fruit juices, in maceration of vegetables to produce pastes and purées and in winemaking, are often produced by fungi, especially by Aspergillus niger. The crushing of pectin-rich fruits results in high viscosity juice which stays linked to the fruit pulp in a gelatinous structure, hindering the juice extraction process by pressing. Pectinase addition in the extraction process improves the fruit juice yield through an easier process, decreases the juice viscosity and degrades the gel structure, thus improves the juice concentration capacity (Kashyap et al. 2001). In case of fruit juice, extraction by enzymatic maceration can increase yields by more than $90 \%$ compared to conventional mechanical juicing, besides improving the organoleptic (color, flavor) and nutritional (vitamins) properties and technological efficiency (ease of filtering) (Rombouts and Pilnik 1980). In several processes, pectinolytic enzymes are applied in association with other cell wall degrading enzymes such as cellulases and hemicellulases (Bhat 2000). The mixture of pectinases and cellulases has been reported to improve more than $100 \%$ juice extraction yields (Kashyap et al. 2001). Soares et al. (2001) reported an improvement between three and four times in juice yields from papaya, banana and pear using enzymatic extraction instead of the conventional pressing process. The enzymatic treatment can help in decrease of $62 \%$ of the apple juice viscosity. When the depectinized apple juice is ultrafiltered, the permeate flux is much higher than undepectinized juice. The increase in the permeation rate is a result of both reduction in apple juice viscosity and total pectin content. Pectin is a fiber shaped colloid that causes severe fouling of ultrafiltration membranes (Alvarez et al. 1998). The commercially available pectinase preparations used in food processing are traditionally associations of polygalacturonases, pectin lyases and pectin methyl esterases. 
These preparations are usually derived from fungi, mainly from the genus Aspergillus (Gummadi and Panda 2003; Semenova et al. 2006). Among filamentous fungi, the genus Aspergillus is well recognized in different industries as it has the ability to produce many extracellular enzymes for nutrition and can use cheapest substrates to sustain and carry out its life processes. Filamentous fungi of genus Aspergillus have therefore received attention towards the development of expression secretion systems aiming at the economic production of high-valued industrial enzymes.

Agro industrial residues have been reported to be the suitable substrate for economic production of pectinase (Kiran Kumar et al 2011). Fungal species have been studied extensively for the production of industrially proficient pectinase enzymes because of their ability to use complex and low cost substrates for growth and maintenance (Kumar and Duhan 2011). Most commonly used agro wastes used as substrates include sugar cane bagasse, wheat bran, rice bran, maize bran, gram bran, wheat straw, rice straw, rice husk, soy hull, sago hampes, grapevine trimming dust, saw dust, corn cobs, banana waste etc. Among such substrates, wheat bran, however, occupies the key place and has most commonly been used in various processes.

Therefore, the present investigation aimed at the economic production of pectinase using both free and immobilized cells of $A$. terreus NCFT 4269.10. Further, applications of this enzyme have been evaluated for its industrial compatibility and suitable use.

\section{Materials and methods}

\subsection{Collection of agro wastes and inoculum preparation}

Banana peels (BP), saw dust (SD) and wheat bran (WB) were collected and dried at $60^{\circ} \mathrm{C}$ for $48 \mathrm{~h}$ or more until the moisture content was reduced. Cooled samples were later grounded in a blender and kept in sterile containers until required. The funga strain, Aspergillus terreus NCFT 4269.10 (GenBank accession Number: KT222271) was maintained on PDA/Sabouraud dextrose agar slants at $4^{\circ} \mathrm{C}$. Spore suspension $(1 \mathrm{ml})$ having spore concentration of about $1 \times 10^{7}$ cells ml $^{-1}$ from 7 days old culture was used as inoculums in the experiments (Sethi et al. 2013).

\subsection{Crude pectinase production by fermentation}

In $150 \mathrm{ml}$ capacity Erlenmeyer flasks, $50 \mathrm{ml}$ of sterilized fermentation medium having individually $\mathrm{BP}, \mathrm{SD}$ and $\mathrm{WB}$ as substrate was inoculated with $1.0 \times 10^{7}$ cells $\mathrm{ml}^{-1}$ from 7 days old cultures of $A$. terreus and incubated at $30 \pm 2{ }^{\circ} \mathrm{C}$ both at liquid static and shaking condition. After $96 \mathrm{~h}$, samples were processed for recovery of pectinase and its activity assay. The fermented broth $(50 \mathrm{ml})$ cultures were centrifuged at $10,000 \mathrm{rpm}$, at $4^{\circ} \mathrm{C}$ for $10 \mathrm{~min}$ to obtain the crude supernatant as crude pectinase for pectinase activity assay. Further, the clear crude supernatant was passed three times through Whatman No. 1 filter paper before pectinase production assay. The remaining crude enzyme was preserved at $-20^{\circ} \mathrm{C}$ for further use.

\subsection{Pectinase assay}

Pectinase activity was performed as per the standard method of Khairnar et al. (2009).Test sample are prepared by mixing $4.9 \mathrm{ml}$ of $0.5 \%$ pectin solution in $0.1 \mathrm{ml}$ of pectinase, $5.0 \mathrm{ml}$ of $\mathrm{I}_{2} / \mathrm{KI}$ solution $(50 \mathrm{M} / 200 \mathrm{mM}), 1 \mathrm{ml}$ of $1 \mathrm{M} \mathrm{Na}_{2} \mathrm{CO}_{3}, 2 \mathrm{ml}$ of $\mathrm{H}_{2} \mathrm{SO}_{4}(2 \mathrm{M})$ and 1-2 drops of pectin indicator. Blank was prepared without adding enzyme in the reaction mixture.All reagents were mixed by gentle shaking. Titrated the Test and Blank with $\mathrm{Na}_{2} \mathrm{~S}_{2} \mathrm{O}_{3}(100 \mathrm{mM})$ until it became light yellow. Then 1 drop of pectin indicator was added and continuously titrated with $\mathrm{Na}_{2} \mathrm{~S}_{2} \mathrm{O}_{3}$ until solution became colorless.

Protein concentrations of the crude pectinase were determined according to Lowry et al. (1951) method taking Bovine Serum Albumin (BSA) as the standard.

\subsection{Measurement of dry cell biomass}

The biomass content was determined by measuring the dry weight from a known amount of sample. The sample was centrifuged at $10,000 \mathrm{rpm}$, at $4^{\circ} \mathrm{C}$ for $10 \mathrm{~min}$ and the fungal biomass was rinsed with sterilized double distilled water and filtered out using Whatman No.1 filter paper. The biomass obtained was dried overnight inside Hot Air Oven at $100^{\circ} \mathrm{C}$ till constant weight was attained. Finally, the dry weight of the fungal mycelia was weighed and calculated (Sethi et al. 2013).

Weight of biomass $=$ weight of dry filter paper with fungal biomass - weight of blank and dry filter paper

[Dry weight of biomass $=$ dry weight of fungus]

\subsection{Partial purification of pectinase}

Partial purification of the crude Whatman paper filtered pectinase supernatant was performed by ammonium sulphate precipitation up to $80 \%$ saturation at $4^{\circ} \mathrm{C}$ of the crude pectinase enzyme. The precipitated protein was recovered by centrifugation at 10,000 rpm for $10 \mathrm{~min}$ at $4^{\circ} \mathrm{C}$ and partially purified by overnight dialysis at $4^{\circ} \mathrm{C}$ against $0.1 \mathrm{M}$ phosphate buffer (pH 6.5) (Jana et al. 2013). Pectinase activity and total protein content of the partially purified enzyme was measured.

\subsection{Immobilization of Aspergillus terreus spores for production of pectinase}

The alginate entrapment of cells/spores was performed according to the method of Sharma and Satyanarayana (2012). To the spore suspension, $3 \%$ of sterilized alginate slurry was mixed well in a ratio of $1: 1$ for 10 minutes to get a uniform mixture. The slurry was taken in a sterile syringe and added drop wise into chilled 0.2 $\mathrm{M} \mathrm{CaCl}_{2}$ solution from 5-cm height and kept for curing at $4{ }^{\circ} \mathrm{C}$ for $1 \mathrm{~h}$. Conidia immobilized in beads of calcium alginate wereaseptically inoculated to sterilized fermentation broth (BP, SD and WB) and incubated at $30^{\circ} \mathrm{C}$ for $96 \mathrm{~h}$. Finally, the fermented media were filtered on Whatman No. 1 paper and beads were washed twice with sterile saline solution $(0.8 \% \mathrm{NaCl})$ and kept in phosphate buffer (1M, pH 7.0). Then, the beads were again introduced into the fresh medium. After attaining maximum production of enzymes, the spent medium was replaced with fresh production medium $(50 \mathrm{ml})$ and the process was repeated for five batches until the beads/blocks started disintegrating. The enzyme titers and cell leakage of each cycle were determined.

\subsection{Ethanol production using agro-wastes}

The fermentation broth media $(500 \mathrm{ml})$ for ethanol production were prepared using BP, SD and WB as the substrates. The flasks containing the sterilized fermentation media were aseptically inoculated with Saccharomyces cerevisiae.In another flask, S. cerevisiae co-cultivated with $A$. terreus and sealed tightly with wax so as to prevent the air flow. In co-cultivation experiment, the fermentation medium was first inoculated with A. terreus and incubated for $48 \mathrm{~h}$ at $30^{\circ} \mathrm{C}$. The spent fermentation medium was then inoculated with $S$. cerevisiae and incubated for another 10 days at $30 \pm 2{ }^{\circ} \mathrm{C}$ under anaerobic condition. The fermentation and production of ethanol were checked by the bubbles $\left(\mathrm{CO}_{2}\right)$ formed during the process and change of color of aqueous calcium hydroxide to white milky color. The fermented matter was allowed to settle for 1 day and then distillation was carried out for the recovery of ethanol.

Similarly, the sterilized fermentation media were aseptically treated with pectinase and cellulase individually and also in combinations $(1: 1)$ and incubated for $2 \mathrm{~h}$ at $50^{\circ} \mathrm{C}$. After that, the fermentation media were aseptically inoculated with $S$. cerevisiae and incubated for another 10 days at $30 \pm 2{ }^{\circ} \mathrm{C}$ under anaerobic condition. After the successful fermentation, the fermented broth was allowed to settle for 1 day and then distillation was carried out for the recovery of ethanol. 
The fermented matter was transferred to alcohol distillation unit and sealed properly. Ethanol recovery was carried out at $68 \pm 2{ }^{\circ} \mathrm{C}$ for $3 \mathrm{~h}$ and the distillate was collected in screw capped bottles, sealed with para film and finally kept in refrigerator at $4^{\circ} \mathrm{C}$.

The ethanol content of the fermented broth was determined by measuring the specific gravity of the distillate according to the procedure described by Amerine and Ough (1984).

\subsection{Enzymatic extraction and clarification of apple juice}

Apples purchased from local market were washed, peeled and cut into small pieces. Ascorbic acid $(0.5 \mathrm{~g} / \mathrm{kg})$ was added and the cut apples were mashed using a food processor for $30 \mathrm{sec}$. To the mash, $1 \mathrm{ml} / 100 \mathrm{~g}$ of enzyme were added and extraction was carried out at $30{ }^{\circ} \mathrm{C}$ and $52 \pm 2{ }^{\circ} \mathrm{C}$ for $30 \mathrm{~min}, 60 \mathrm{~min}, 90 \mathrm{~min}$ and 120 min respectively. The treated mash was heated to $90{ }^{\circ} \mathrm{C}$ for $5 \mathrm{~min}$ in a water bath to inactivate the enzymes. Juice from the mash was separated by centrifugation at 6000 rpmfor $10 \mathrm{~min}$ and pomace was discarded.

Juice yield $(\%)=($ Final juice weight $/$ Initial mash weight $) \times 100$

Clarity of juice was measured according to the method of Krop and Pilnik (1974). Percent transmittance was determined at 660 nm using a UV-Vis spectrophotometer.

The content of pectinacious materials present in the apple juices was measured in terms of alcohol-insoluble-solids (AIS). AIS were determined by boiling $5 \mathrm{~g}$ juice with $75 \mathrm{ml} 80 \%$ ethanol, simmering for $30 \mathrm{~min}$ and filtering through Whatman No. 1 filter paper. The filtered residue was washed again with $80 \%$ ethanol. The residue was dried at $100^{\circ} \mathrm{C}$ for $2 \mathrm{~h}$ and expressed in percentage by weight (Hart and Fisher 1971). The density of juice was determined using a specific gravity bottle.

\subsection{Fermentation kinetics study}

Various fermentation kinetics parameters were also calculated (Sethi et al. 2015). They include Ye/s (yield of enzyme per gram of substrate), $\mathrm{Yx} / \mathrm{s}$ (yield of biomass per gram of substrate), $\mathrm{Ye} / \mathrm{x}$ (yield of enzyme per gram of biomass), $\mathrm{dx} / \mathrm{dt}$ [biomass accumulation in the culture medium $\left(\mathrm{g} \mathrm{l}^{-1} \mathrm{~h}^{-1}\right)$ ], $\mathrm{dP} / \mathrm{dt}$ [enzyme accumulation in the culture medium $\left.\left(\mathrm{U} \mathrm{ml}^{-1} \mathrm{~h}^{-1}\right)\right], \mu_{\max }$ [highest specific growth rate observed during batch culture $\left.\left(\mathrm{mgl}^{-1} \mathrm{~h}^{-1}\right)\right], \mathrm{x}_{\max }[$ maximum attainable biomass $\left.\left(\mathrm{mg} \mathrm{ml}^{-1}\right)\right], \alpha$ [growth associated coefficient of enzyme production $\left(\mathrm{U} \mathrm{g}^{-1}\right)$ ], $\beta$ [growth-independent coefficient of enzyme production $\left.\left(\mathrm{U} \mathrm{g}^{-1} \mathrm{~h}^{-1}\right)\right]$.

\subsection{Statistical analysis}

Statistical analysis was performed by SPSS, version 10 for windows (SPSS Inc; Chicago, IL, USA).

\section{Results and discussion}

Various agro-wastes like wheat bran (Zea mays L.), banana peels (Musa paradisiaca L.) and sawdust was screened individually for the selection of suitable substrate required for optimum production of pectinase. The nature and chemical composition of the substrate is also one of the most important parameter that greatly affects fermentation processes. Among various substrates used for the production of pectinase in LSSF, banana peels as the substrate supported maximum production of pectinase i.e. 1000 \pm 141.42 $\mathrm{U} / \mathrm{ml}$ when A. terreus was used for fermentation in BP fermentation medium. About half of the pectinase production $(600 \pm 141.42$ $\mathrm{U} / \mathrm{ml}$ ) was obtained using saw dust as the sole carbon source (Table 1). Similarly, the total protein content of the crude extracts was different when the fermentation was carried out with different substrates. Maximum protein content was found in the crude enzyme extract when the fermentation was carried out in static condition using banana peels $(724.28 \pm 56.39 \mu \mathrm{g} / \mathrm{ml})$ (Fig. 1). After successful fermentation, the biomass was separated, processed and estimated. It is concluded that the maximum biomass of $A$. terreus was obtained with wheat bran $(0.55 \pm 0.07 \mathrm{~g} / 50 \mathrm{ml})$ as compared to other substrates taken for this study. Banana peels were used as the substrate owing to its high pectin content which can be exploited very well as India has the first position in banana production which is about 16 million tons per year (Jacob et al. 2008). The use of other substrates (wheat bran, orange peel, sugar cane peel and banana peel) revealed the preference of banana peels by the isolates for pectinase production which is at par with the findings of Torimiro and Okonji (2013).

Table 1: Specific Activity of Pectinase Produced by A. terreus

\begin{tabular}{lllll}
\hline Fungus & Substrates & $\begin{array}{l}\text { Pectinase activi- } \\
\text { ty }(\mathrm{U} / \mathrm{ml})\end{array}$ & $\begin{array}{l}\text { Total protein } \\
(\mathrm{mg} / \mathrm{ml})\end{array}$ & $\begin{array}{l}\text { Specific } \\
\text { activity } \\
(\mathrm{U} / \mathrm{mg})\end{array}$ \\
\hline \multirow{4}{*}{$\begin{array}{l}\text { A. } \\
\text { terreus }\end{array}$} & $\begin{array}{l}\text { Sawdust } \\
\text { Banana } \\
\text { peels }\end{array}$ & $600 \pm 141.42$ & $0.46 \pm 0.08$ & 1295.05 \\
& $\begin{array}{l}\text { Wheat } \\
\text { bran }\end{array}$ & $1000 \pm 141.42$ & $0.78 \pm 0.05$ & 1285.18 \\
\hline
\end{tabular}

Liquid shaking fermentation was carried out to find out the suitable shaking rate (rpm) and suitable fermentation type for the production of pectinase for its application in industrial sectors. It was concluded from the results that shaking fermentation was suitable for the production of enzyme using A. terreus. The shaking fermentation study revealed that maximum pectinase was produced using banana peels $(1250 \pm 212.13 \mathrm{U} / \mathrm{ml})$ as the sole source of carbon at $100 \mathrm{rpm}$ by A. terreus (Fig. 1). Similarly, maximum protein was also obtained from BP fermentation medium. Liquid shaking fermentation using orange peels by A. terreus at $120 \mathrm{rpm}$ for $96 \mathrm{~h}$ at $30^{\circ} \mathrm{C}$ was suitable than static condition for pectinase biosynthesis (Sethi et al. 2015). 


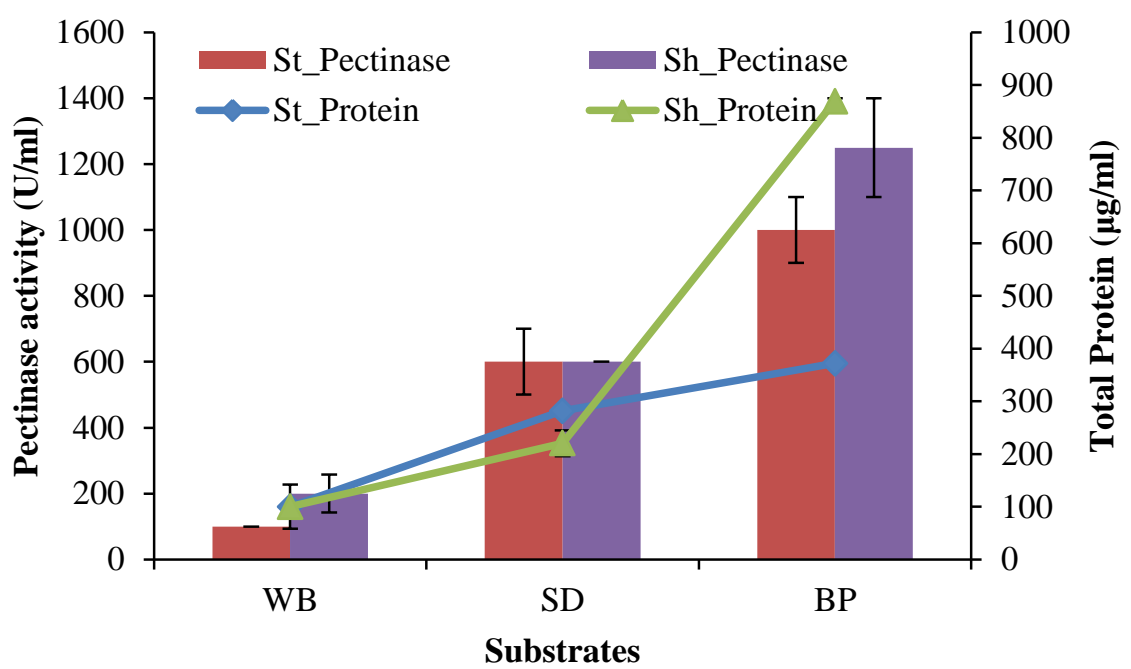

Fig. 1:Production of Pectinase, Total Protein and Sugar Released in Liquid Static Surface Fermentation and Liquid Shaking Fermentation using Banana Peels (BP), wheat Bran (WB) and Saw Dust (SD) as Substrates by A. Terreus ( $\mathrm{St}=\mathrm{Static}$ Condition; Sh= Shaking Condition)

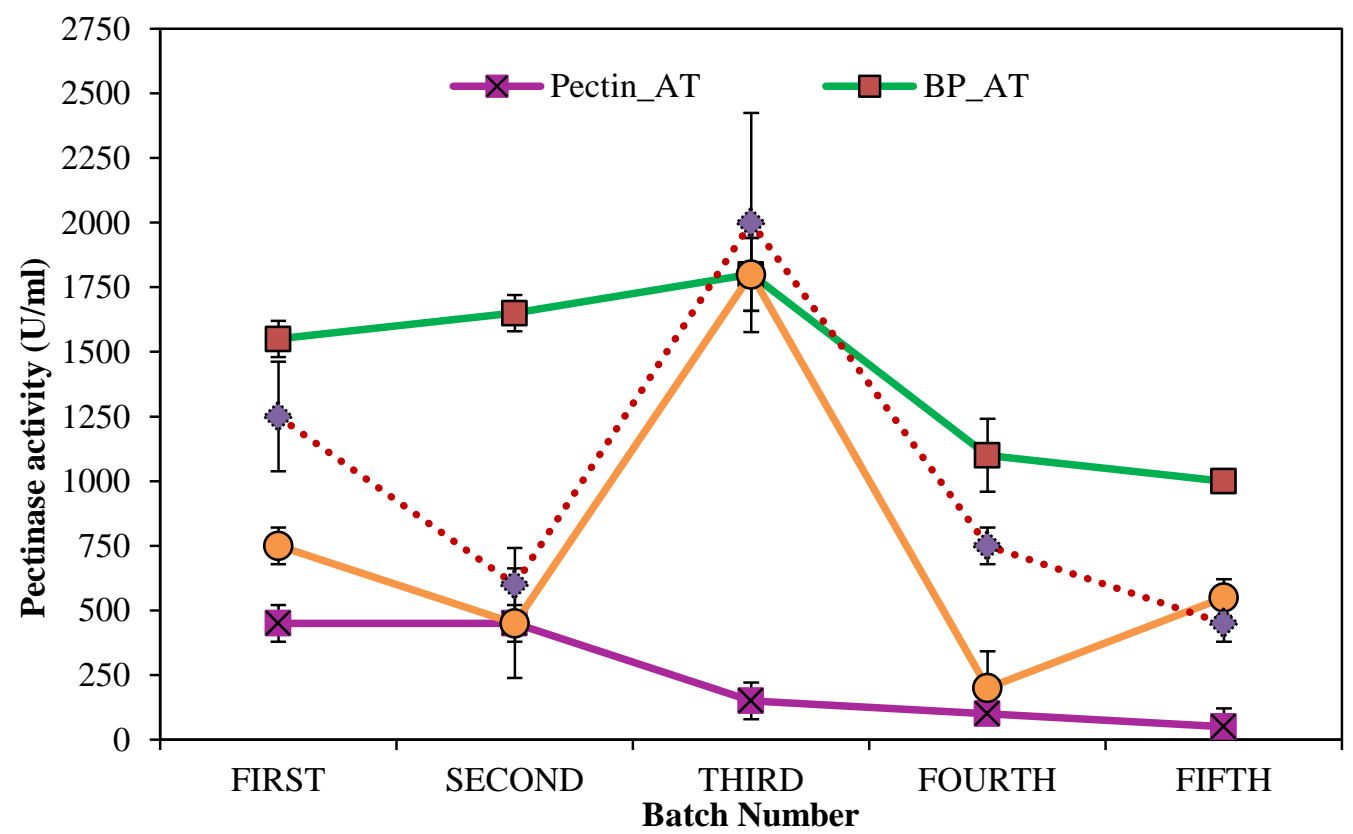

Fig. 2:Production of Pectinase Using Calcium Alginate Beads Entrapping the Spores of A. terreus Using Repeated Batch Cultures. (AT: Aspergillus terreus)

Out of these three agro waste (banana peels, wheat bran and saw dust) banana peel showed highest enzyme activity in both the fermentation process, hence, pectinase enzyme extracted from banana peel are used for further purification, ethanol production and apple juice clarification activity.

Due to the maximum purification of pectinase enzyme from lower range to higher range, the initial maximum enzyme activity (Maximum enzyme activity at static condition) was taken into consideration. The enzyme was purified to electrophoretic homogeneity with a specific activity of $1846.50 \mathrm{U} / \mathrm{mg}$ of protein from an initial specific activity of $1282.05 \mathrm{U} / \mathrm{mg}$ of protein. After dialysis, the cell free-dialyzed-enzyme containing $107100 \mathrm{U}$ was purified to 1.44 fold and the overall enzyme yield was $35.70 \%$ (Table 2). The analysis of enzyme activity in the crude extract does not indicate either an isolated action or the presence of a multi-enzymatic system working in synergy on the substrate degradation. The characterization of purified enzymes is an important research line since it provides discrimination between the enzymatic complex components about substrate degradation mechanism, optimum activity conditions and enzyme synthesis regulation. Higher fold of purification of crude pectinase enzyme than the present investigation was also reported before (Celestino et al. 2006).
Table 2: Partial Purification of Isolated Crude Pectinase by A. terreus

\begin{tabular}{|c|c|c|c|c|c|c|c|}
\hline Step & $\begin{array}{l}\text { Vol- } \\
\text { ume } \\
(\mathrm{ml})\end{array}$ & $\begin{array}{l}\text { Ac- } \\
\text { tivity } \\
(\mathrm{U} / \mathrm{ml} \\
)\end{array}$ & $\begin{array}{l}\text { Total } \\
\text { en- } \\
\text { zyme } \\
\text { activ- } \\
\text { ity } \\
\text { (U) }\end{array}$ & $\begin{array}{l}\text { Total } \\
\text { pro- } \\
\text { tein } \\
(\mathrm{mg})\end{array}$ & $\begin{array}{l}\text { Spe- } \\
\text { cific } \\
\text { activ- } \\
\text { ity } \\
(\mathrm{U} / \mathrm{m} \\
\mathrm{g})\end{array}$ & $\begin{array}{l}\text { Purifica- } \\
\text { tion fold }\end{array}$ & $\begin{array}{l}\text { Yie } \\
\text { ld } \\
(\%)\end{array}$ \\
\hline Crude & 300 & 1000 & $\begin{array}{l}3000 \\
00\end{array}$ & 234 & $\begin{array}{l}1282 . \\
05\end{array}$ & 1 & 100 \\
\hline $\begin{array}{l}\text { Ammo- } \\
\text { nium } \\
\text { sulphate } \\
\text { precipi- } \\
\text { tation }\end{array}$ & 44 & 4100 & $\begin{array}{l}1804 \\
00\end{array}$ & 103 & $\begin{array}{l}1751 . \\
45\end{array}$ & 1.37 & $\begin{array}{l}60 . \\
13\end{array}$ \\
\hline Dialysis & 17 & 6300 & $\begin{array}{l}1071 \\
00\end{array}$ & 58 & $\begin{array}{l}1846 . \\
50\end{array}$ & 1.44 & $\begin{array}{l}35 . \\
70\end{array}$ \\
\hline
\end{tabular}

The reusability of alginate immobilized fungi for pectinase production was evaluated. Beads entrapping A. terreus spores (Fig. 3) were successfully employed in 5 repeated cycles in the presence of pectin, banana peels, saw dust and wheat bran as the carbon sources. When pectin was used as the carbon source, the activity of pectinase increased slightly with the use of recycled beads up to second cycle and fell thereafter. The production of pectinase in- 
creased up to third cycle and drastically decreased thereafter when banana peels were used as the substrate for the production of pectinase by the immobilized spores of $A$. terreus. Further, the disintegration of beads started at the late phase of fourth cycle in case of A. terreus. Similarly, when wheat bran was taken for the production of pectinase, the biosynthesis of pectinase by A. terreus was continued up to fifth cycle displaying highest production at third cycle. The disintegration of beads started from the late phase of third cycle. The production of pectinase was not uniform in case of saw dust supplemented fermentation medium for both immobilized spores of A. terreus. However, the production of pectinase was utmost at third cycle and drastically decreased thereafter in case of $A$. terreus.

Immobilization of microbial cells and enzymes has become one of the most valuable tools in the field of biotechnology (El-Katatny et al. 2003). Moreover, microbial entrapment gives prolonged metabolic activity when microbial cells are reused and protects the organism from inhibitory compounds or metabolites.

The partially purified enzyme was used for the production of ethanol. The pre-processed pectinaceous agro-wastes (banana peels) were treated with the partially purified enzyme for $2 \mathrm{~h}$ and the enzymatic hydrolyzed substrate was used for the production of ethanol by fermentation using Saccharomyces cerevisiae as the fermentative organism. Three different conditions were maintained for the ethanol production. It was concluded from the Table 3 that the enzyme treated substrate was able to produce highest amount of alcohol with high purity as compared to untreated and co-cultivated fermentation conditions (Table 3). The alcohol weight $(\%)$ of the distillated alcohol was also estimated. Alcohol weight $(\%)$ produced by enzyme treated substrate was found to be highest i.e. $91.5 \%$, with compare to other experimental conditions (Table 3). Many literatures revealed that the supplementation of pectinolytic enzymes tends to increase the level of methanol in pectic substrates because of the activity of pectin methyl esterase.

Table 3: Production of Ethanol from Enzyme Treated and Untreated Banana Peels

\begin{tabular}{|c|c|c|c|c|}
\hline $\begin{array}{l}\text { Treatment of } \\
\text { substrate }^{\text {a }}\end{array}$ & $\begin{array}{l}\text { Specific } \\
\text { gravity at } \\
20^{\circ} \mathrm{C}\end{array}$ & $\begin{array}{l}\text { Alcohol } \\
\text { weight per- } \\
\text { centage }\end{array}$ & $\begin{array}{l}\mathrm{g} / 10 \\
0 \mathrm{ml}\end{array}$ & $\begin{array}{l}\text { Volume } \\
\text { percent- } \\
\text { age }\end{array}$ \\
\hline $\begin{array}{l}\text { Only } S . \text { cerevisiae } \\
\text { cells }\end{array}$ & 0.9917 & 22 & $\begin{array}{l}21.8 \\
5\end{array}$ & 27.5 \\
\hline $\begin{array}{l}\text { S. cerevisiae }+A \text {. } \\
\text { terreus } \text { spores }\end{array}$ & 0.9917 & 22 & $\begin{array}{l}21.8 \\
5\end{array}$ & 27.5 \\
\hline $\begin{array}{l}\text { Pectinase_AT }+S \\
\text { cerevisiae cells }\end{array}$ & 0.9502 & 91.5 & 89.3 & 112.5 \\
\hline
\end{tabular}

The fermentation medium for production of ethanol was prepared using only banana peel as the substrate. (Pectinase_AT: pectinase produced by Aspergillus terreus NCFT 4269.10)

Therefore, an attempt has been taken for the bioconversion of the pectic substrates to fermentative substrate by fungal enzymes for ethanol production using $S$. cerevisiae.

Pectins present in juices are responsible for the turbidity and consistency of the juice causing an increase in their viscosity which hinders its clarification, filtration and concentration (Alkorta et al. 1998). The degradation of pectic substances in mashed fruit purees is possible through the addition of pectinase resulting in an enhanced juice yield and its clarification as well as a decrease in viscosity. Treatment with pectinases also provides filtering of the product (Ribeiro et al. 2010). Hence enzymatic treatments of apple fruit juice are carried out at $30^{\circ} \mathrm{C}$ (temperature treatment). As pectinases are the chief component for the fruit juice manufacturing process, their activities under the suitable conditions were studied for apple juice preparation. Higher juice yield and clarity were obtained with only partially purified pectinases at $90 \mathrm{~min}$ of incubation in comparison to only cellulase and pectinase with cellulase treatment (Table 4). Similar results were obtained for the clarification of the juice when treated with only pectinase enzyme. The maximum clarity $(80 \%)$ was obtained at $30 \mathrm{~min}$ of incubation when pectinase was used as enzyme source (Table 4).
In the case of apple juice, the most frequently used enzymes are those that can depolymerize the highly esterified apple pectin. Juice from apple can be achieved through two-step process consisting of a first treatment of the crushed apple mush with pectinases to get the premium juice followed by pomace liquefaction i.e. treating with a different proportion of pectinases and cellulases for the complete extraction of the juice (Will et al. 2000). Hence in the present study extraction and clarification of the apple juice was carried out by both cellulase and pectinase treatment (Table 4).

Table 4: Enzymatic Extraction of Apple Juice Using Partially Purified Pectinase

\begin{tabular}{|c|c|c|c|c|c|}
\hline $\begin{array}{l}\text { Treat- } \\
\text { ment } \\
\text { Duration }\end{array}$ & $\begin{array}{l}\text { Enzyme } \\
\text { applica- } \\
\text { tion }\end{array}$ & $\begin{array}{l}\text { weight of } \\
\text { only pom- } \\
\text { ace }(\mathrm{g})\end{array}$ & $\begin{array}{l}\text { weight of } \\
\text { only juice } \\
\text { (g) }\end{array}$ & $\begin{array}{l}\% \text { of } \\
\text { juice } \\
\text { yield }\end{array}$ & $\begin{array}{l}\text { Clari- } \\
\text { ty } \\
(\% \\
\text { Trans } \\
\text { mit- } \\
\text { tance } \\
\text { at } 660 \\
\text { nm) }\end{array}$ \\
\hline \multirow{4}{*}{$30 \mathrm{~min}$} & Control* & 1.112 & 1.363 & 0 & 0.3 \\
\hline & Cellulase & 0.769 & 1.536 & 62.06 & 31.3 \\
\hline & $\begin{array}{l}\text { Pectinase } \\
\text { cellulase }\end{array}$ & 0.207 & 1.67 & 67.47 & 80.9 \\
\hline & $\begin{array}{l}+ \text { pecti- } \\
\text { nase }\end{array}$ & 0.922 & 1.575 & 63.64 & 21.4 \\
\hline \multirow{3}{*}{$60 \mathrm{~min}$} & Cellulase & 0.015 & 1.668 & 67.39 & 38.9 \\
\hline & $\begin{array}{l}\text { Pectinase } \\
\text { cellulase }\end{array}$ & 0.223 & 1.685 & 68.08 & 68 \\
\hline & $\begin{array}{l}+ \text { pecti- } \\
\text { nase }\end{array}$ & 2.25 & 1.575 & 63.63 & 29.6 \\
\hline \multirow{3}{*}{$90 \mathrm{~min}$} & Cellulase & 0.198 & 1.67 & 67.47 & 27.6 \\
\hline & $\begin{array}{l}\text { Pectinase } \\
\text { cellulase }\end{array}$ & 0.3 & 1.737 & 70.18 & 52.9 \\
\hline & $\begin{array}{l}+ \text { pecti- } \\
\text { nase }\end{array}$ & 0.911 & 1.679 & 67.83 & 19.4 \\
\hline \multirow{3}{*}{$120 \mathrm{~min}$} & Cellulase & 0.34 & 1.699 & 68.65 & 19.7 \\
\hline & $\begin{array}{l}\text { Pectinase } \\
\text { cellulase }\end{array}$ & 0.527 & 1.733 & 70.02 & 46.5 \\
\hline & $\begin{array}{l}+ \text { pecti- } \\
\text { nase }\end{array}$ & 0.93 & 1.726 & 69.73 & 17.7 \\
\hline
\end{tabular}

The initial weight of the concentrated apple fruit juice was taken which was found to be $5.87 \mathrm{~g}$. After treatment of the juice with the alcohol as per the procedure described above, the final weight was found to be $1.091 \mathrm{~g}$. Hence, it was concluded from the result that about $81.43 \%$ of alcohol soluble and $18.57 \%$ alcohol insoluble solids were present in the apple fruit juice.

After fermentation, the enzyme and biomass were separated as described above. The yield factors were calculated and presented in the Table 5. It was concluded from the table that the highest specific growth rate of $A$. terreus observed during the fermentation was with wheat bran i.e. $114 \mathrm{mgl}^{-1} \mathrm{~h}^{-1}$ (Table 5). Similarly, the enzyme accumulation in the culture medium per hour $(\mathrm{dP} / \mathrm{dt})$ was highest when banana peels were used as the substrate for A. terre$u s$. The growth associated coefficient of enzyme production $(\alpha)$ was maximum when pectinase was produced using banana peels by A. terreus. But, the growth-independent coefficient of enzyme production $(\beta)$ was optimum when fermentation was carried out by $A$. terreus using wheat bran as the substrate. Similar type of result was also proposed by Iftikhar et al. (2010) for the biosynthesis of lipase from Rhizopusoligosporus var. microsporus. 
Table 5:Fermentation Kinetics of the Pectinase Produced by A. terreus

\begin{tabular}{|c|c|c|c|c|c|c|c|c|c|}
\hline $\begin{array}{l}\text { Opti- } \\
\text { mum } \\
\text { condi- } \\
\text { tions }\end{array}$ & $\begin{array}{l}Y_{\mathrm{e} / \mathrm{s}} \\
(\mathrm{U} / \\
\mathrm{g})\end{array}$ & $\begin{array}{l}\mathrm{Y}_{\mathrm{x} /} \\
\mathrm{s} \\
(\mathrm{g} / \\
\mathrm{g}) \\
\end{array}$ & $\begin{array}{l}\mu \\
\left(\mathrm{h}^{-}\right. \\
\left.{ }^{1}\right)\end{array}$ & $\begin{array}{l}\alpha \\
(\mathrm{U} / \mathrm{g})\end{array}$ & $\begin{array}{l}\beta(\mathrm{U} / \\
\mathrm{g} / \mathrm{h})\end{array}$ & $\begin{array}{l}\mathrm{dx} / \\
\mathrm{dt} \\
(\mathrm{g} / \mathrm{L} \\
/ \mathrm{h}) \\
\end{array}$ & $\begin{array}{l}\mathrm{dP} / \\
\mathrm{dt} \\
(\mathrm{U} / \mathrm{m} \\
\mathrm{l} / \mathrm{h})\end{array}$ & $\begin{array}{l}\mathrm{X}_{\max } \\
(\mathrm{mg} / \\
\mathrm{ml})\end{array}$ & $\begin{array}{l}\mu_{\max } \\
(\mathrm{mg} / \\
\mathrm{L} / \mathrm{h})\end{array}$ \\
\hline SDAT & $\begin{array}{l}600 \\
0\end{array}$ & $\begin{array}{l}0.0 \\
19\end{array}$ & $\begin{array}{l}0 . \\
99\end{array}$ & 53 & & $\begin{array}{l}0.01 \\
9\end{array}$ & 6.25 & 0.99 & 19.85 \\
\hline BPAT & $\begin{array}{l}100 \\
00\end{array}$ & $\begin{array}{l}0.0 \\
46\end{array}$ & $\begin{array}{l}2 . \\
43\end{array}$ & $\begin{array}{l}21404 \\
1.09\end{array}$ & $\begin{array}{l}229 . \\
59\end{array}$ & $\begin{array}{l}0.04 \\
8\end{array}$ & 10.42 & 2.43 & 48.67 \\
\hline $\begin{array}{l}\text { WBA } \\
\mathrm{T}\end{array}$ & $\begin{array}{l}950 \\
0 \\
\end{array}$ & $\begin{array}{l}0.1 \\
12\end{array}$ & $\begin{array}{l}5 . \\
70\end{array}$ & $\begin{array}{l}86805 . \\
55\end{array}$ & $\begin{array}{l}487 . \\
55\end{array}$ & $\begin{array}{l}0.11 \\
4\end{array}$ & 9.89 & 5.70 & 114.0 \\
\hline
\end{tabular}

\section{Conclusion}

Enzymes that hydrolyze pectin and plant based pectic substances have significance in numerous biotechnological applications and even more so in food industries. The employment of these enzymes for bioconversion / hydrolysis of pectic substrates i.e. banana peels and other materials containing large amount of pectin is fundamental to achieve value added products. For these reasons, an escalating demand exists in the biotechnological industries for production of industrial-friendly, stable, highly active and competent enzymes. Several operating strategies have been employed for the production of biotechnologically imperative enzymes by filamentous fungi i.e. mainly from Aspergillus, Trichoderma and Penicillium. The development of technologies that allow the use of organisms or enzymes in bioreactors in various industrial production systems promise to revolutionize fermentation technology. Despite the progress, more studies are still needed to scale-up these applications efficiently to industrial levels

\section{Acknowledgement}

The authors gratefully acknowledge Prof. Ramanuja Nayak, Principal, MITS School of Biotechnology, 2 (P), Infocity, Patia, Chandaka Industrial Estate, Bhubaneswar-751024, Odisha, India for his kind help and necessary laboratory facilities.

\section{References}

[1] Adeleke AJ, Odunfa SA, OlanbiwonninuA \& Owoseni MC (2012) Production of cellulase and pectinase from orange peels by fungi. Nature and Science 10(5), 107-112.

[2] Alkorta I, Gabirsu C, Lhama MJ \& Serra JL (1998) Industrial applications of pectic enzymes: a review. Process Biochemistry 33, 21-8.http://dx.doi.org/10.1016/S0032-9592(97)00046-0.

[3] Alvarez S, Alvarez R, Riera FA \& Coca J (1998) Influence of depectinization on apple juice ultrafiltration. Colloids and Surfaces A: Physicochemical and Engineering Aspects 138, 377 82.http://dx.doi.org/10.1016/S0927-7757(98)00235-0.

[4] Amerine MA \& Ough CS (1984). Wine and must analysis. New York (USA), Wiley.

[5] Beg QK,Kapoor M, Tiwari RP \& Hoondal GS (2001) Bleachboosting of eucalyptus kraft pulp using combination of xylanase and pectinase from Streptomyces sp. QG-11-3. Research Bulletin of Panjab University of Science 51, 71-78.

[6] Bhat MK (2006) Cellulases and related enzymes in biotechnology. Biotechnology Advances, 18, 35583.http://dx.doi.org/10.1016/S0734-9750(00)00041-0.

[7] Celestino SMC, Freitas SM, Medrano FJ, De Sousa MV \& Ferreira-Filho EX (2006) Purification and characterization of a novel pectinase from Acrophialophoranainiana. Journal of Biotechnology 123, 33-42.http://dx.doi.org/10.1016/j.jbiotec.2005.10.024.

[8] Contreas-Esquivel JC \& Voget CE (2004) Purification and partial characterization of an acid polygalacturonase from Aspergillus $\mathrm{ka}$ wakii. Journal of Biotechnology 110, 218.http://dx.doi.org/10.1016/j.jbiotec.2004.01.010.

[9] de Vries RP, Jansen J, Aguilar G, Parenicova L, Joosten V, WulfertF, BenenJA \&Visser J (2002) Expression profiling of pectinolytic genes from Aspergillusniger. FEBS Letter 530, 4147.http://dx.doi.org/10.1016/S0014-5793(02)03391-4

[10] Delgado LAT, Huitron BC \& Aguilar G (1992) Pectin lyase from Aspergillus sp. CH-Y-1043. AppliedMicrobiology andBiotechnology 39, 515-519.http://dx.doi.org/10.1007/BF00205043.
[11] Dhillon SS, Gill RK, Gill SS \& Singh M (2004) Studies on the utilization of citrus peel for pectinase production using Aspergillus niger. International Journal of Environment 61, $199-210$

[12] El-Katatny MH, Hetta AH, Shaban GM \& El-Komy HM (2003) Enzyme Production by Alginate Encapsulated Trichodermaspp. Food Technology \& Biotechnology 41 (3), 219-225.

[13] Fawole OB \& Odunfa SA (2003) some factors affecting production of peptic enzymes by Aspergillus niger. International Biodeterioration \& Biodegradation 52, 223 227.http://dx.doi.org/10.1016/S0964-8305(03)00094-5.

[14] Gummadi SN \& Panda T (2003) Purification and biochemical properties of microbial pectinases - a review. Process Biochemistry 38, 987-96.http://dx.doi.org/10.1016/S0032-9592(02)00203-0.

[15] Iftikhar T, Niaz M, Zia MA \& Haq IU (2010) Production of extracellular lipases by Rhizopus oligosporusin a stirred fermentor. Brazilian Journal of Microbiology 41, 1124-1132. http://dx.doi.org/10.1590/S1517-83822010000400034.

[16] Jacob N, Poorna AC \& Prema P (2008) Purification and partial characterization of polygalacturonase from Streptomyces lydicus. $\begin{array}{lll}\text { Bioresource } & \text { Technology } & 99,\end{array}$ 701.http://dx.doi.org/10.1016/j.biortech.2007.10.002.

[17] Jana A, Maity C, Halder SK, Das A, Pati BR, Mondal KC \& Das Mohapatra PK (2013) Structural characterization of thermostable, solvent tolerant, cytosafe tannase from Bacillus subtilis PAB2. Biochemical Engineering Journal 77, 161170.http://dx.doi.org/10.1016/j.bej.2013.06.002.

[18] Kashyap DR, Vohra PK, Chopra S \& Tewari R (2001) Applications of pectinase in the commercial sector: a review. Bioresource Technology $\quad 77, \quad 215-227$. http://dx.doi.org/10.1016/S09608524(00)00118-8.

[19] Khairnar Y, Vamsi KK, Boraste A, Gupta N, Trivedi S, Patil P, Gupta G, Gupta M, Jhadav A, Mujapara A, Joshi B \& Mishra D (2009) Study of pectinase production in submerged fermentation using different strains of Aspergillus niger. International Journal of Microbiological Research 1, 13-17.http://dx.doi.org/10.9735/09755276.1.2.13-17.

[20] KropJJP \& PilnikW (1974) Effect of pectic acid and bivalent cations on cloud loss of citrus juice. Lebensmittel-Wissenschaft undTechnologie 7, 62-73.

[21] Kumar A \& Duhan JS (2011) Production and characterization of amylase enzyme isolated from Aspergillusniger MTCC-104 employing solid state fermentation. International Journal of Pharam\& Bio Science 3(2), 250-258.

[22] Miranda OA, Salgueiro AA, Pimentel MCB, Lima Filho JL, Melo, EHM \& Dur'an N (1999) Lipase production by a Brazilian strain of Penicilliumcitrinumusing an industrial residue. Bioresource Technology 69, 145-147. http://dx.doi.org/10.1016/S09608524(98)00166-7.

[23] Mosier N \& Wyman C (2005) Features of promising technologies for pretreatment of lignocellulosic biomass. Bioresource Technology 96, 673-686.http://dx.doi.org/10.1016/j.biortech.2004.06.025.

[24] Naidu GSN \& Panda T (1998) Production of pectolytic enzymes: a review. Bioprocess Engineering 19, 355-361. http://dx.doi.org/10.1007/PL00009023.

[25] Namasivayam E, Ravindar JD, Mariappan K, Akhil J, Mukesh K \& Jayaraj RL (2011) Production of extracellular pectinase by Bacillus cereus isolated from market solid waste. Journal of Bioanalysis\& Biomedicine $\quad 3, \quad$ 070-075.http://dx.doi.org/10.4172/1948593X.1000046.

[26] Pedrolli DB (2008) Caracterizaçãofisico-química de pectinases extracelularespurificadas de Aspergillus giganteus. M.Sc. Thesis, São Paulo State University, Rio Claro, São Paulo, Brazil.

[27] Reid I \& Richard M (2004) Purified pectinase lowers cationic demand inperoxide-bleached mechanical pulp. Enzyme \& Microbial Technology 34 ,

499 504.http://dx.doi.org/10.1016/j.enzmictec.2003.12.005.

[28] Ribeiro DS, Henrique SMB, Oliveira LS, Macedo GA \& Fleuri LF (2010) Enzymes in juice processing: a review. International Journal of Food Science and Technology 45, 635641.http://dx.doi.org/10.1111/j.1365-2621.2010.02177.x.

[29] Rombouts FM \& Pilnik W (1980) Pectic enzymes. In Rose AH, Ed. Microbial Enzymes and Bioconversions Academic Press, London, 5, pp. 227-72

[30] Salazar L \& Jayasinghe U (1999) Fundamentals of purification of plant viruses. In Techniques in plant virology CIP. Training Manual JO Virus Purification Int Potato Centre, Peru, pp. 1-10.

[31] Semenova MV, Sinitsyna OA, Morozova VV, Fedorova EA, Gusakov AV, Okunev ON, Sokolova LM, Koshelev AV, Bubnovalu P \& Sinitsyn AP (2006) Use of a preparation from fungal pec- 
tin lyase in the food industry. Applied Biochemistry and Microbiology 42, 598-602.http://dx.doi.org/10.1134/S000368380606010X.

[32] Sethi BK, Nanda PK \& Sahoo SL (2016) Enhanced production of pectinase by Aspergillus terreus NCFT 4269.10 using banana peels as substrate. 3 Biotech 6, 36-51.http://dx.doi.org/10.1007/s13205015-0353-y.

[33] Sethi BK, Panda B \& Sahoo SL (2015) Biosynthesis of industrially relevant extracellular pectinase from Aspergillus terreus NCFT 4269.10 using orange peels as substrate. Asian Journal of Biotechnology 7, 1322.http://dx.doi.org/10.3923/ajbkr.2015.13.22.

[34] Sethi BK, Rout JR, Das R, Nanda PK \&Sahoo SL (2013) Lipase production by Aspergillus terreus using mustard seed oil cake as a carbon source. Annals of Microbiology 63, 241252.http://dx.doi.org/10.1007/s13213-012-0467-y.

[35] Sharma DC \& Satyanarayana T (2005) A marked enhancement in the production of a highly alkaline and thermostable pectinase by Bacillus pumilus desr1 in submerged fermentation by using statistical methods. Bioresource Technology 97, 727733.http://dx.doi.org/10.1016/j.biortech.2005.04.012.

[36] Singh SA, Ramakrishna M \& Rao AGA (1999) Optimization of downstream processing parameters for the recovery of pectinase from the fermented broth of Aspergillus carbonarious. Process Biochemistry $\quad 35, \quad 411-417$. http://dx.doi.org/10.1016/S00329592(99)00089-8.

[37] Soares MMCN, da Silva R, Carmona EC \& Gomes E (2001) Pectinolytic enzyme production by Bacillus species and their potential application on juice extraction. Journal of Microbiology \& Biotechnology 17, 79-82.http://dx.doi.org/10.1023/A:1016667930174.

[38] Torimiro N \& Okonji RE (2013) a comparative study of pectinolytic enzyme production by Bacillus species. African Journal of Biotechnology 12(46), 6503.http://dx.doi.org/10.5897/AJB2013.12421.

[39] Vibha B \& Neelam G (2010) Exploitation of microorganisms for screening of pectinase from environment. 8th International Conference. Globelics.

[40] Viikari L, Tenakanen M \& Suurnakki A (2001) Biotechnology in the pulp and paper industry. In Rehm HJ, editor, Biotechnology, VCH-Wiley,

$\mathrm{pp}$

523 546.http://dx.doi.org/10.1002/9783527620937.ch18.

[41] Whitaker JR (1990) Microbial pectinolytic enzymes. In Fogarty WM, Kelly CT, editors. Microbial enzymes and biotechnology 2nd ed. Elsevier Science Ltd, London, pp. 133176.http://dx.doi.org/10.1007/978-94-009-0765-2_4.

[42] Will F, Bauckhage K \& Dietrich H (2000) Apple pomace liquefaction with pectinases and cellulases: analytical data of the corresponding juices. Europian Food Research Technology 211, 291297.http://dx.doi.org/10.1007/s002170000171.

[43] Yamaski M, Yasui T \& Arima K (1964) Pectic enzymes in the clarification of apple juices. Part I Study on the clarification reaction in a simplified model. Agricultural \& Biological Chemistry 28, 779. 787. 